\title{
Acute Ecotoxicological Effects of Bauxite Residue Addition on Mortality and Motion-frequency of Dendrobaena veneta and Enchytraeus albidus (Annelida) in Three Types of Soils
}

\author{
Ivett Kriszta Kerekes*, Éva Pusztai², Sándor Kemény²
}

1 Zoology and Animal Ecology Research Group, Faculty of Agricultural and Environmental Sciences,
H-2100 Gödöllö, Károly Páter Street 1, Hungary
2 Department of Chemical and Environmental Process Engineering, Faculty of Chemical Technolg
University of Technology and Economics, H-1111 Budapest, Budafoki Street 8, Hungary
${ }^{*}$ Corresponding author, e-mail: kerekes.ivett.kriszta@phd.uni-szie.hu

Received: 09 March 2021, Accepted: 02 June 2021, Published online: 13 August 2021

\section{Abstract}

The bauxite residue is produced in high amount all over the world. This indurate is a possiblu the material has been producing in high amount, it is not frequent to it. We investigated its annelid species: Dendrobaena veneta and Enchytraeus albidus. Two forr and gypsum neutralized) and three natural soils (NH: Nagyhörcsök, N Nyírlugos, OB: Ö ttyán) were examined. To determine the safe concentration in short term, the acute mortality and sublethal b vior tests (per altic motion-frequency) were performed. The bauxite residue addition (<5/10 \%) raised the $\mathrm{pH}$ water holdin soils. Both types of the bauxite residue increased the motion-frequency of the worms. The unt teanan acuternortality effect (> $25 \%$ ). Both species refused the higher concentration soils ( $\geq 10 \%$ ) of both types of bauxite sidue. $\$$ of annelids in acidic sandy soils because of the $\mathrm{nH}$ level and

Keywords bauxite residue, soil-ecotoxicology,

\section{Introduction}

The bauxite resid is produced $0>2$ tons each to alumina production [1]. This mate As alkaline and high, line [2]. The bauxite residu a widely y material e.g. In chemical processes, const ion-, enmental addition [3-5]. Moreover, the bauxite a suitab oil amendment material [5-7] differ metals [8-10]. Although 140 million is [11] w duced a year and it has to be stored wi Latantial risks, less than 4 million tons are utilized [5]. The anmon are important decompositor groups. They can affect the soil physical and chemical parameters $[12,13]$ increase the plant production [14]. Both the earthworms and nchytraeidae (potworms) are recommended ecotoxicological test organisms. The systematically examined endpoints are the mortality, reproduction and avoidance (or preference) $[15,16]$. The following guidelines prescribe the method of determining the above-mentioned endpoints in environmental risk assessment processes [17-24].
Only a few studies focused on the potential effects of bauxite residue on annelids. Maddock et al. [25] tested how the Metal-Loaded Bauxol Reagent (MLBR), produced from bauxite residue, affected the mortality, weight gain and metal uptake of earthworm (Eisenia fetida). The MLBR did not cause mortality in the test population. In higher concentrations $(60 ; 80 \%)$ the animals lost weight. Courtney et al. [26] found that the Allolobophora chlorotica species did not tolerate the effects of untreated bauxite residue, none of them survived it. The test population survived the organically or/and gypsum treated samples, but lost weight during the test. The $A$. longa species tolerated only control soil and bauxite residue from the 12-year-old field restored site. Di Carlo et al. [27] found that the fresh unrehabilitated bauxite residue had mortal effect on Eisenia fetida (LC50:37 $\pm 3.6 \%$ ). When the bauxite residue addition was more than $25 \%$, it was significantly impacted survival (> $28 \%$ ) and reproduction 
(inhibition $>76 \%$ ). Finngean et al. [28] examined the Eisenia fetida area choose tests. They found that most of the total test population (54\%) selected the younger field site which contained $25 \%$ gypsum treated bauxite residue.

Kerekes and Feigl [29] found that, the Enchytraeus albi$d u s$ species chose a bauxite residue treated soil $(1 ; 5 \%)$ in a soil preference test, when the concentrations did not exceed more than $10 \%$. Although the bauxite residue has been produced in high amount and it has more options for technological utilization, there are just a little information about the effects concerning annelids in natural soils. We would like to investigate how the bauxite residue affect in different physical-chemical parameters (such as $\mathrm{pH}, \mathrm{WHC}-$ Water Holding Capacity, metal content) of natural soils.

We aimed to determine the safe concentration of bauxite residue in different natural soils related to annelids. In order to answer this question, we added two types of bauxite residue to three different natural soils. The mixed samples were examined with acute lethal and behavior (peristaltic-motion-frequency) tests by two species (Dendrobaena veneta, Enchytraeus albid, The motion-frequency as pre-screening endpoint prot information about energy consumption of organisn The energy consumption has indirect effect on the survi ing of the population. Moreover, this en prs data about the active mitigation behavio
2 Material and methods 2.1 Materials and experiy cal set-up Two different types of $y$ collected in Hungary (Ajka; $5^{\prime} 18.4$, 17³2'52.0 E) [30]. The first one $y$ untreated and red in a deposit (S; $\mathrm{pH}=10.4 \pm 0$ 2016. The second was collected as its count art, but $t^{\prime}$ material was filter pressed [31] and neu red $y^{\prime}$ gypsum $(2 \%)(\mathrm{G} ; \mathrm{pH}=9.4 \pm 0.0)$. To investigo effects of axite residue as soil ameateria, baux esidue types were mixed with three d erent typ ungarian soils (Table 1 [32-34]). The ficandy soil (NY: $\mathrm{pH}=4.9$ ) was originated from ugos. Trum sareous sandy soil (OB: $\mathrm{pH}=7.7)$ was lected from Örbottyán. The silty soil $(\mathrm{NH}: \mathrm{pH}=7.6)$ wa riginated from Nagyhörcsök.

Thu wo bauxite residue types were mixed to the soils in various concentrations (w/w\%) (Table 2). We tested both more physical-chemical parameters $(\mathrm{pH}, \mathrm{WHC}-$ Water Holding Capacity, XRF - X-Ray Fluorescence spectroscopy as total element content) and ecotoxicological endpoint.
Table 1 Soil properties a Texture [32], b Water Holding Capacity [33], c Humus, c $\mathrm{CaCO}_{3}$, c pH [34] (NH: Nagyhörcsök, NY: Nyírlugos, OB: Örbottyán)

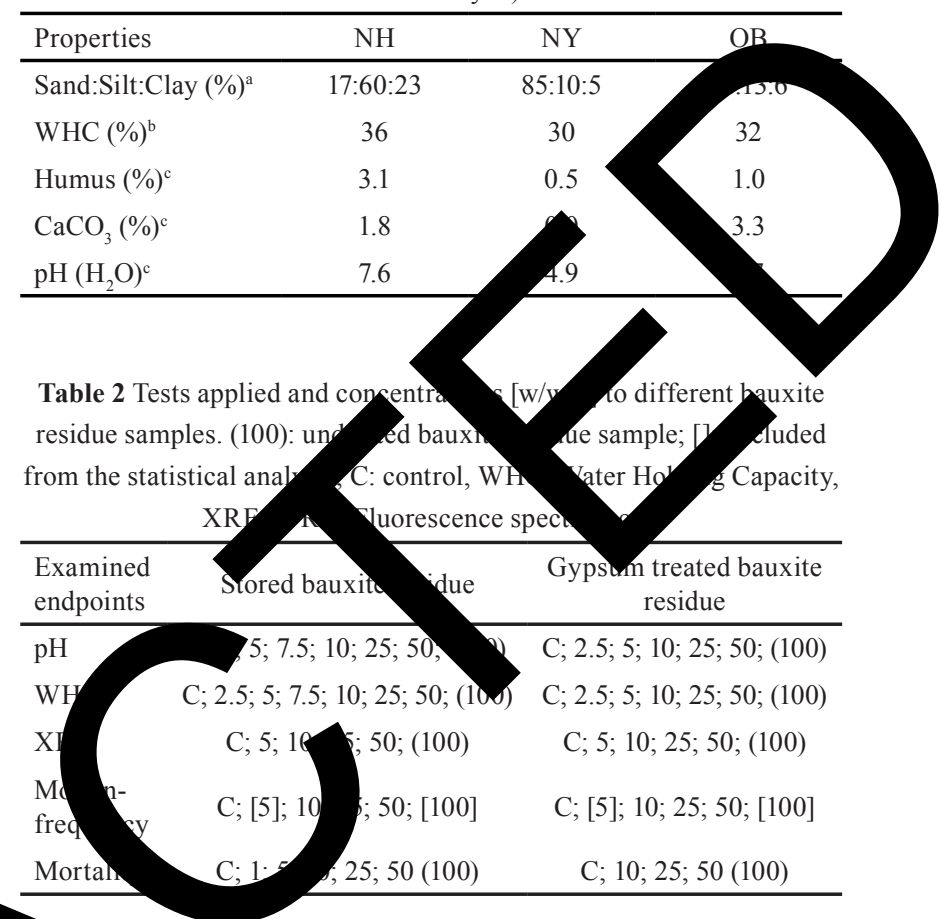

7 areated natural soils were used as control. s a pre-rial experiment, we made the following test (Subsections 2.2, 2.4 and 2.5) with undiluted bauxite residue samples $(\mathrm{S} ; \mathrm{G})$ but just with one control $(\mathrm{NH})$. After these pre-trial experiments, we tested the mixed samples (Table 2). Dried, mixed and sieved $(<2 \mathrm{~mm})$ forms of the samples were used for testing.

\subsection{Characterization of soil properties}

The $\mathrm{pH}$ was measured in 1:2.5 soil: distilled water suspension after 30 minutes shaking at $160 \mathrm{rpm}$ [34]. The $\mathrm{pH}$ level was typified by classes according to USDA (Table 3) [35]. The total element content was measured by XRF method with NITON XL3t 600. The WHC was measured by Schinner's method [33]. All the tests were made in three, independent replicates at the same time.

Table 3 Class term of $\mathrm{pH}$ level in case of soils [35]

\begin{tabular}{lccc}
\hline Class term & $\mathrm{pH}$ range & Class term & $\mathrm{pH}$ range \\
\hline Ultra-acid & $<3.5$ & Neutral & $6.6-7.3$ \\
Extremely-acid & $3.5-4.4$ & Slightly alkaline & $7.4-7.8$ \\
Very-strongly-acid & $4.5-5.0$ & Moderately alkaline & $7.9-8.4$ \\
Strongly-acid & $5.6-6.0$ & Strongly alkaline & $8.5-9.0$ \\
Slightly-acid & $6.1-6.5$ & Very strongly & $>9.0$ \\
\hline
\end{tabular}




\subsection{Test organisms}

The Enchytraeus albidus (described the species in 1837 by Henle) originated from the Budapest University of Technology and Economics, Faculty of Chemical Technology and Biotechnology stock culture. We made a mixed base-culture from the used stock boxes before the testing, which were stored on $20 \pm 2{ }^{\circ} \mathrm{C}$. Only adult (had clitellum) animals with appropriate length $(1-1.5 \mathrm{~cm})$ were tested.

The Dendrobaena veneta (described the species in 1886 by Rosa) organism were bought from special shops. The organisms starved for 2 days in a mixed base-culture (boxes covered water saturated filter paper) before the tests. During the starving period the organic material amount eliminated from the digestion system, so it was not able to work as puffer material. The boxes were stored protected from direct light at constant temperature $\left(20 \pm 2{ }^{\circ} \mathrm{C}\right)$. We selected the adult worms to be tested which were long enough $(5-8 \mathrm{~cm})$.

\subsection{Acute mortality tests}

In case of $E$. albidus the acute mortality test formed according to OECD 207 modified for ench by OECD 220 [23]. Shortly, we measured $20 \mathrm{~g}$ soil nd watered the $60 \%$ of WHC. We placed 5 animals in vessel (as replicates; glass "jar": These were stored at constant ten tected from light. After the exp ber of refused, died or to did not react on tactile rulus

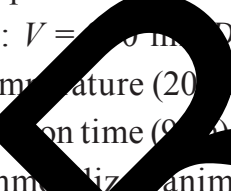
$\mathrm{P}=6 \mathrm{ch}$ $\left.{ }^{\circ} \mathrm{C}\right)$, pro 10 animals (uruve anted. We called an animal "refused" they were ali nd stayed in the top layer of so nstead urrowing the ower layers. In case of veneta the $\mathrm{OE}$ [22] guide was followed, by reduced the mass on soil sample to $120 \mathrm{~g}$ (accor sto Lour et al.'s [36] method ) we used a double o. eir vol which was $20 \mathrm{~g}$ /animal dry weight from ct ligh constant temperature $\left(20 \pm 2{ }^{\circ} \mathrm{C}\right)$. The fused (di arrow layer), died or totally immobiy dranimals were counted after 7 and 14 days. Three, aepenarmaticates were examined.

Motion frequency endpoint

Wo plied new endpoint, the motion-frequency (behavior) test supplementing the mortality test in order to gain extra information. This test was made before the acute mortality test on the same test organisms in order to avoid the further disturbance caused by the placing. This endpoint was examined in an extra observation time during the mortality test process in the same test vessels.
We defined "motion frequency" as the number of moves in a time unit. The peristaltic motion includes one body part length changing from the shortest to the longest state of body parts. As it is a subjective displacement, op-rorver performed all the tests to reduce this part of certain

Having put one animal in the ves normalization time. The normalization always took $1-10$-seconds and it ended whe anim started to move in a well-definable lip If the normalization time 10 seconds, we exclud

The motions of onds which on Before exam ng organism, almost cons each anj was mo test series. vious one burrowed to wer layer to avoid influencing each $y$ animals (depended on the ny oer of excluded animals, $n$ each test vessel. Three, fependent replic es were examined. 2. tatistical and rathematical analyses TIB 13.4. software was used to perform the tatisticaranalysis. Significance level $(\alpha)$ was set as 0.05 alyses. Abbreviations both in the table and in the models. $\mathrm{BR}=$ type of bauxite residue (two levels: $\mathrm{S}, \mathrm{G}$ ); Soil = type of soil (three levels: NY, NH, OB); Conc $=$ concentration of the examined bauxite residue (levels are given in Table 3) in the soil.

Soil properties: Two-sample $t$-test was used to compare the two, undiluted bauxite residue samples (100\%) in the case of $\mathrm{pH}$ and WHC. Three-way analysis of variance (ANOVA) was used to decide which factors affected the WHC concerning other concentrations (2.5-50\%). The fitted ANOVA model contained three fixed factors (Table 2) in crossed design. Due to the absence of replications, only the main effects (BR, Soil, Conc) may have been evaluated.

Mortality tests: The mortality was analysed by $2 \times 2$ frequency tables in case of undiluted bauxite residue samples $(100 \%)$. Other method was applied by other concentrations $(2.5-50 \%)$. The statistically sound way to evaluate the mortality as dependent variable would have been the logistic regression. Since the occurrences of non-event (zero) in more factor-combinations, it caused numerical difficulties in estimating parameters of the logistic regression model [37]. A rescue was to use ANOVA for the transformed mortality values. Angular transformation (arcus sinus of square root) function was used to have an approximately normally distributed dataset of constant variance. First, three fixed factors (BR, Soils, Conc), their interactions and the random effect of the reactor were evaluated. 
The latter was nested in the third order interaction dictated by the experimental design. The effect of the reactor was not significant in this case either.

Motion-frequency test: The motion-frequency is a Poisson distributed random variable (count data), thus this dataset was evaluated with Poisson regression (GLZ: Generalized Linear Model) separately for the two examined test species. In case of undiluted samples (100\%) the silty soil (NH) was the chosen reference level in the Poisson regression model. The only factor was the medium related to soil or bauxite residue types. In case of other concentrations (2.5-50\%), the fitted model contained the three effects and their interactions in case of investigating the effect of bauxite residue addition (as Subsection 2.2). A random factor i.e. the test vessels was added to both models, as well. The levels of the vessels could be interpreted only within one combination of the other three factors which means that it was nested in the three-way interaction. The analysis of variance on the square root transformed dependent variable was performed to check if we could get rid of this effect. As the effect of the random factor was not significant, in the final GLZ m only the effects of the crossed structure of the other factors were evaluated with Type III likelihood-ratio t The assumptions of the model were checked and accepted For analysis, it should have been noted th Ratio (LR) test statistics follows chi-so e distrib on only
in the case of large sample sizes [38

Moreover, we calculated "S two test species, which a de was used both the undil

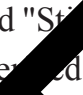
clati compare un xite residue sà es (100\%) and other concentrat s (2.5- too. We usedne pieces of moving (as $\mathrm{P}$ on data) by th value facilitated th omparison of relativo concerning test speci forme following:

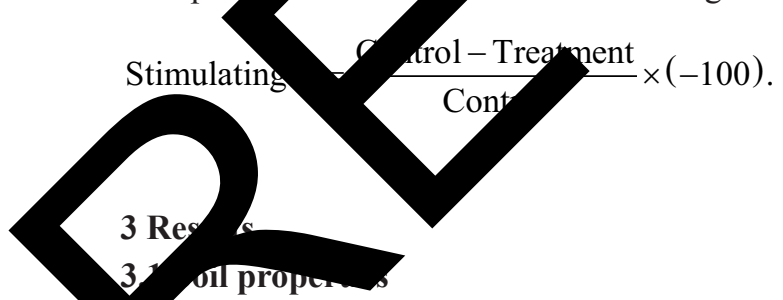

3 oil propumar

e treatment of bauxite residue could influence the propen Both bauxite residue types (100\%) had significantly gher $\mathrm{pH}$ and WHC levels than the reference one (NH). The treatment of bauxite residue reduced significantly both the $\mathrm{pH}$ level (S:10.4 $\pm 0.1 ; \mathrm{G}: 9.4 \pm 0.0)$ and water holding capacity (S:51.8 $\pm 3.4 ; \mathrm{G}: 33.4 \pm 1.0$ ). It did not change severally the composition of elements (Table 4).
Table 4 Total element concentrations by X-Ray Fluorescence spectroscopy (G: gypsum treated-, S: stored bauxite residue)

\begin{tabular}{l} 
Element \\
\hline $\mathrm{As}$ \\
$\mathrm{Co}$ \\
$\mathrm{Cr}$ \\
$\mathrm{Cu}$ \\
$\mathrm{Hg}$ \\
$\mathrm{Mo}$ \\
$\mathrm{Ni}$ \\
$\mathrm{U}$ \\
$\mathrm{Zn}$ \\
$\mathrm{V}$
\end{tabular}

C) one. Onty $\%$ untreated bauxite residue (S) addity the $\mathrm{pH}$ in the neutral class (Table 3). In case of eated one $(\mathrm{G})$ maximum $5 \%$ addition affected beneficially so rose the $\mathrm{pH}$ level by neutral zone (Fig. 1).

The NOEC (No Observed Effective Concentrations) depended on the soil type (the highest safe examined concentrations: NH-G:C; NH-S:C; NY-G:10 \%; NY-S:5 \%; OB-G:5 \%; OB-S:5\%). Typically, $5 \%$ or $10 \%$ bauxite residue addition caused risky metal-concentration. Concerning the three metals together the highest safe concentration depended on the original metal contamination of control soil (Table 5, Appendix A [39, 40]).

The three main effects were significant for water holding capacity (Table 6, Appendix B) interaction effects may not be tested. The water holding capacity was more increased
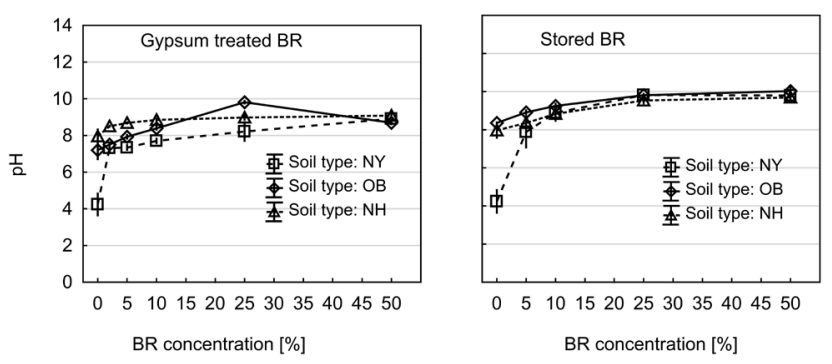

Fig. 1 Dependence of $\mathrm{pH}$ level on BR concentrations for different types of soil and bauxite residue types (means with $95 \%$ confidence intervals) (BR: bauxite residue, NH: Nagyhörcsök, NY: Nyírlugos, OB: Örbottyán) 
Table 5 The safe concentration in case of different types of soil related to three examined metals (As, Cr, V). "Safe" was when the amount of metal did not higher than threshold value. (NH: Nagyhörcsök, NY: Nyírlugos,

OB: Örbottyán, G: gypsum treated-, S: stored bauxite residue)

\begin{tabular}{lcccccc}
\hline & \multicolumn{2}{c}{$\mathrm{NH}$} & \multicolumn{2}{c}{$\mathrm{NY}$} & \multicolumn{2}{c}{$\mathrm{OB}$} \\
& $\mathrm{G}$ & $\mathrm{S}$ & $\mathrm{G}$ & $\mathrm{S}$ & $\mathrm{G}$ & $\mathrm{S}$ \\
\hline $\mathrm{As}$ & $\mathrm{C}$ & $\mathrm{C}$ & $10 \%$ & $5 \%$ & $5 \%$ & $5 \%$ \\
$\mathrm{Cr}$ & $5 \%$ & $\mathrm{C}$ & $10 \%$ & $10 \%$ & $10 \%$ & $5 \%$ \\
$\mathrm{~V}$ & $25 \%$ & $25 \%$ & $25 \%$ & $25 \%$ & $25 \%$ & $25 \%$ \\
$\mathrm{NOEC}$ & $\mathrm{C}$ & $\mathrm{C}$ & $10 \%$ & $5 \%$ & $5 \%$ & $5 \%$ \\
\hline
\end{tabular}

Table 6 ANOVA for the effects of factors on Water Holding Capacity (BR: bauxite residue, Soil: examined soil type, Conc: concentration of bauxite residue)

\begin{tabular}{lccccc}
\hline & Sum of Squares & $\begin{array}{c}\text { Degr. of } \\
\text { Freedom }\end{array}$ & $M S$ & $F$ & $P$ \\
\hline BR & 317.89 & 1 & 317.89 & 17.893 & 0.000 \\
Soil & 4491.50 & 2 & 2245.75 & 126.410 & 0.000 \\
Conc. & 1548.68 & 5 & 309.74 & 17.435 & 0.000 \\
Error & 1261.36 & 71 & 17.77 & & \\
\hline
\end{tabular}

by untreated bauxite residue (S) than by the tre (G). Although almost all the concentrations of bau idue increased the WHC level, this effect was statist lly significant only in the higher concentrations ( $>$ The water holding capacity improving
case of sandy soils (NY, OB) with ginally ld higher case of sandy soils (NY, OB) with ginally lo er WHC.

\subsection{Mortality tests of two} -spe Both undiluted bauxite due (100\% sed severe mortality by Dendrobae ta test species. average surviving (after 14 do was $2 \pm 38.5 \%$, S. $.6 \pm 50.9 \%$, but the diffe between types of bauxite residue was significant. In case nchytraeus albidus test sp es, the a age surviving was G:93.4 $11.5 \%$, S:0 0 and difference between the two types of bauxite (100\%) y significant. All the survived

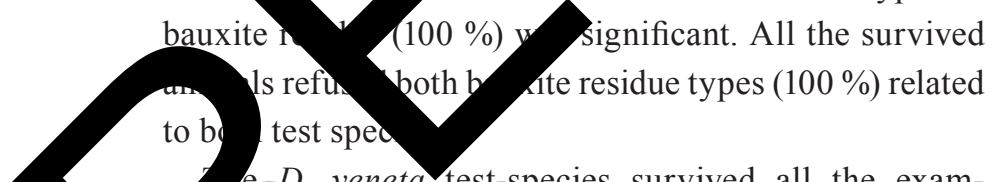
D veneta test-species survived all the examed concenums. On the contrary the animals totally refused the $\leq 10 \%$ (S) or $\leq 25 \%$ (G) concentrations. E. albidus survived almost all of the examined concenations of gypsum treated bauxite residue $(\mathrm{G})$ in each soil. Similarly, the $D$. veneta test species, the E. albidus totally refused the $10 \%$ or higher concentrations of this bauxite residue $(\mathrm{G})$ related to all types of soils. Only the untreated bauxite residue (S) caused meaningful mortality (> $20 \%$ ) (Table 7, Fig. 2).
Table 7 The ANOVA table of the transformed mortality and the investigated factors and interactions (BR: bauxite residue, Soil: examined soil type, Conc: concentration of bauxite residue)

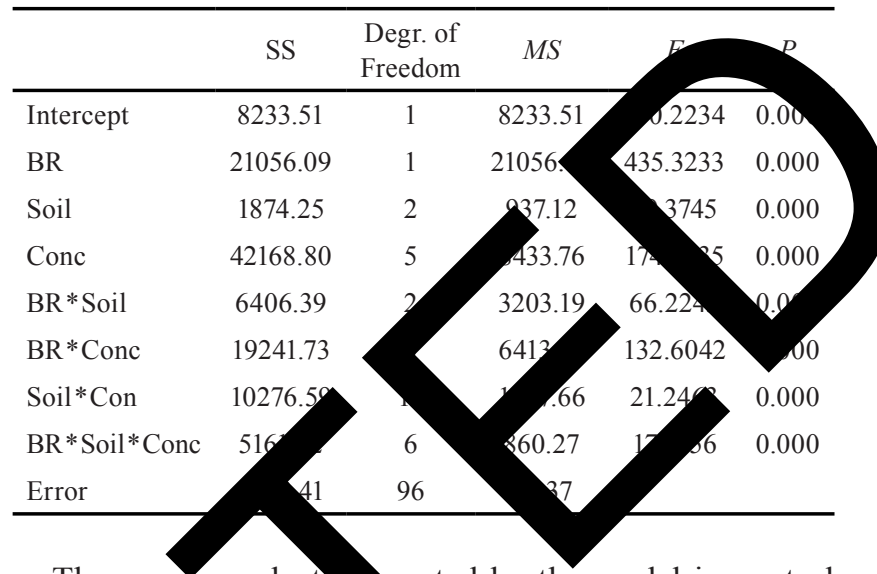

There was no death vected by the model in control soils lower concen (1-5\%) of bauxite resi$n$ the calcareous sandy $(\mathrm{OB})$, the $10 \%$ concentran reduced signif antly the surviving in test population. case of other tw ypes of soils (NH, NY), the $25 \%$ and 5 concentratio affected significantly. The mortality was hiohe the higher concentrations $(25 ; 50 \%)$ of calcareous sandy soil (OB).

\subsection{Moron-frequency tests}

The Enchytraeus albidus was sensitive to undiluted bauxite residue (100 \%). Both types of bauxite residue (G, S) increased significantly the peristaltic motion-frequency of animals compared to the control (NH). The treated sample (G:137.4 $\pm 0.0 \%$ ) caused less motion-frequency stimulation than the untreated one (S:141.6 $\pm 19.7 \%$ ). The difference between the bauxite residue types was not significant. Examining the other levels of BR concentration, the bauxite residue addition increased the peristaltic motion-frequency of E. albidus (Table 8, Fig. 3).

Every investigated effect was statistically significant by both test species. As it was mentioned in Material and methods valid part (2.5), the Chi-Square and $p$-values was less reliable, the graph (Fig. 3) was instructed.

The parameter estimates and the calculated values give more reasonable information about the effects. The expected motion-frequencies were similar in the two sandy soils (NY, OB) related to both bauxite residue types $(\mathrm{G}, \mathrm{S})$. The untreated bauxite residue addition caused higher changes. The lowest motion-frequency was found in the silty control soil (NH:4.85) which was the reference level. For the treated bauxite residue $(\mathrm{G})$ the motion- frequency was 0.85 times lower than for the other (S). If this type (G) was added to the soils, the effect of the treatment depended 

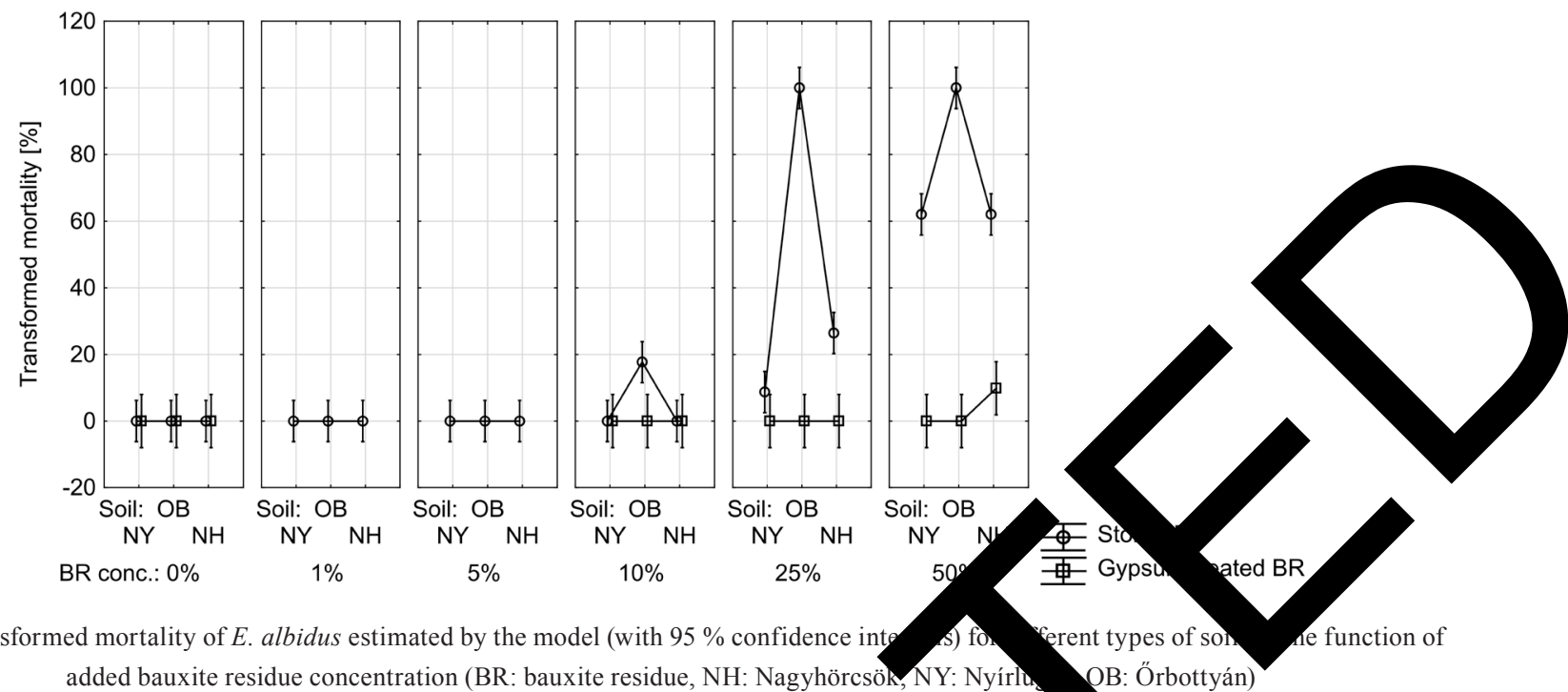

Fig. 2 Transformed mortality of E. albidus estimated by the model (with $95 \%$ confidence in added bauxite residue concentration (BR: bauxite residue, $\mathrm{NH}$ : Nagyhörc

Table 8 Type III likelihood-ratio test for the main effects and interactions on motion-frequency of $E$. albidus and $D$. veneta (BR: bauxite residue, Soil: examined soil type, Conc: concentration of bauxite residue)

\begin{tabular}{c}
\hline $\begin{array}{c}\text { Degr. of } \\
\text { Freedom }\end{array}$ Log-Likelihood Chi-Square $P$ \\
\hline Enchytraeus albidus
\end{tabular}

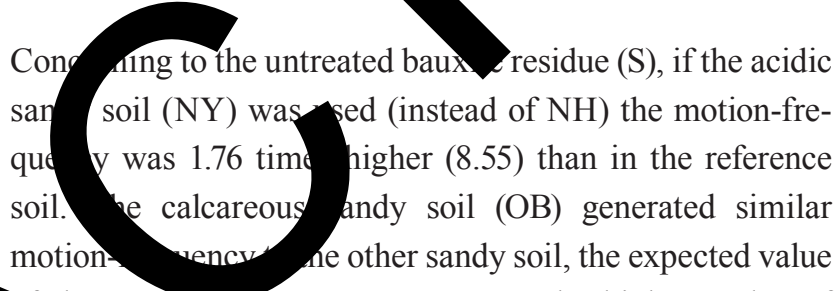
the motion- irequency was 8.40. The highest value of BR

Soil Conc $\mathrm{BR} *$ Soil 37411.88 11.3 BR*Conc 37360.50

Soil*Conc 2 253.8

\section{BR*Soil*Conc}

BR

Soil

Conc $\mathrm{BR} *$ Soil BR* Con Soil $*$ Co Soil * BR *CO on the of the these ased sigmmantly only at the $50 \%$ dose of BR comred to the control soil (C). In sandy soils (NY, OB) the tro of the increase in motion frequency was very similar to eac ther but it differs from the case of silty soil $(\mathrm{NH})$. This tendency was not observable by untreated bauxite residue (S). There is an interaction between the types of bauxite residue and concentrations factors. In addition, it could be observed that the interaction between the soil type and conc. depends on the type of BR (three-way interaction). m muencies was predicted by the $50 \%$ concentration untreated bauxite residue $(\mathrm{S})$ with sandy soils (NY:12.00; OB:12.15). Compared to these soils (NY, OB), the silty soil (NH) resulted only 9.60 motion-frequency value.

The Dendrobaena veneta test species was sensitive to undiluted bauxite residue $(100 \%)$. Both bauxite residue types (G, S) increased significantly the peristaltic motion-frequency of animals compared to the control (NH). The untreated (S:70.8 $\pm 7.9 \%$ ) sample caused higher motion-frequency stimulations than the treated one (G:58.3 $\pm 7.0 \%$ ). The difference between the bauxite residue types was not significant. Based on LR values the concentration of the added bauxite residue was the most important factor in case of $D$. veneta (Table 8, Fig. 4).

The changes of motion-frequency were different in case of different types of soils and/or bauxite residue types (interaction between soil- and bauxite residue types). The control soils (without bauxite residue) showed more similar behavior in connection with the motion-frequency than in case of E. albidus. With stored sample (S) in the silty $(\mathrm{NH})$ and calcareous sandy $(\mathrm{OB})$ soils it resulted approx. 1.7 times higher expected value in the motionfrequency than with acidic sandy (NY) soil. Although the motion-frequency increased by concentration, the effect was influenced by the type of soil and bauxite residue. The test-organism reacted similar motion-frequency 

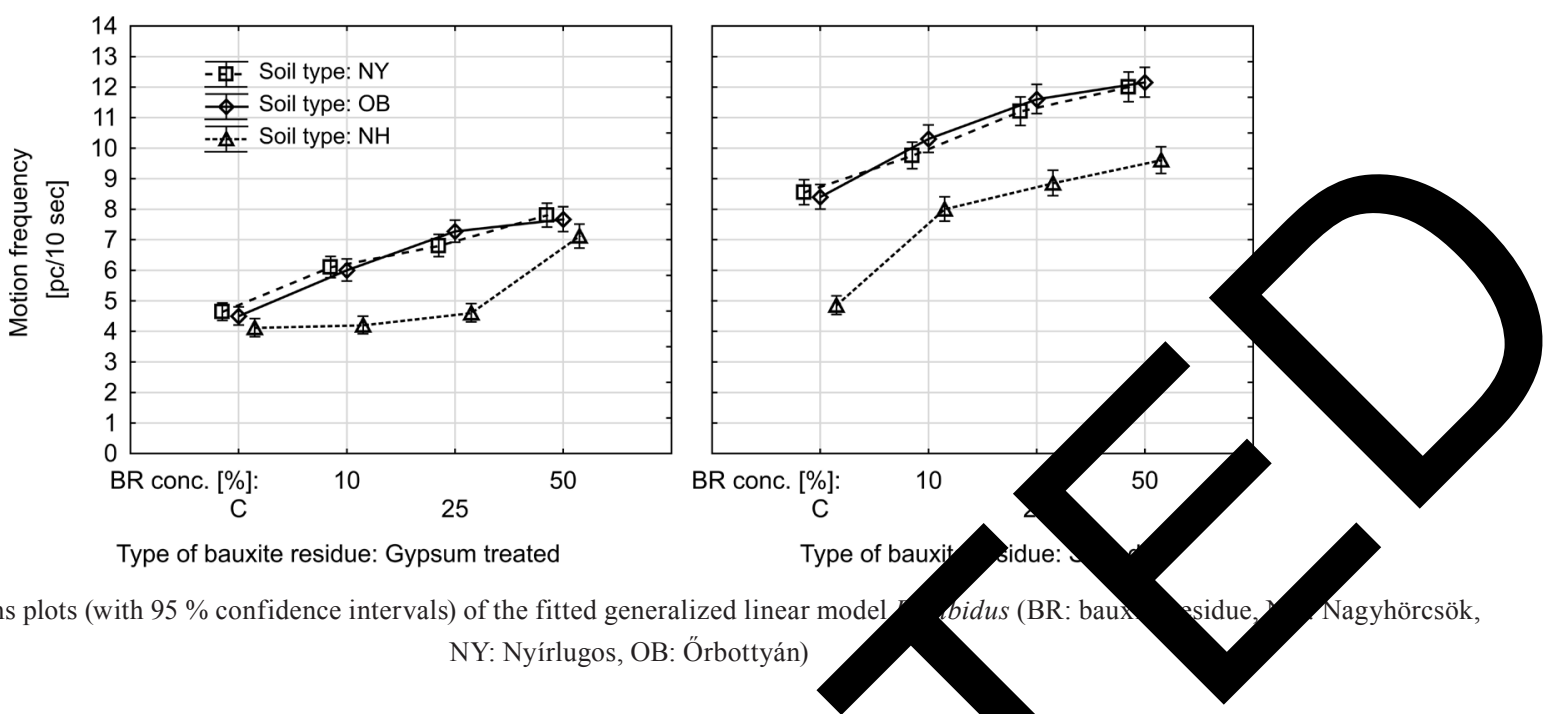
Fig. 3 The LS means plots (with $95 \%$ confidence intervals) of the fitted generalized linear
NY: Nyírlugos, OB: Örbottyán)

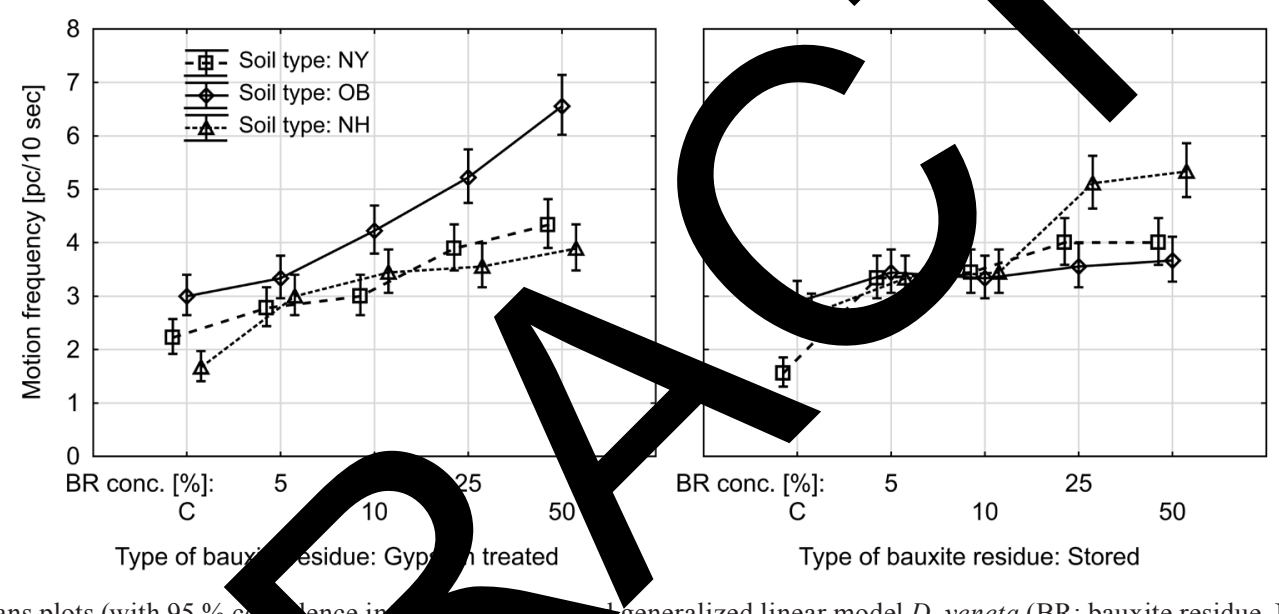

Fig. 4 The LS means plots (with 95\% cd gence in $\quad$ NY: Nyírlugos, OB: Örbottyán)

changes in $5 \%$ bay vidue concent as in gypsum treated baux In case of unceated bauxite residue (S) concentrat were the $5 \%$ and $10 \%$ added cop drations (Fig. 4).

The test-spe $s$ reacted differently to bauxite residue a ion ( $\mathrm{T}^{2} 9$, Appendix $\left.\mathrm{C}\right)$. The motion-frequency changes eneta were Nays lower. The treated baux-

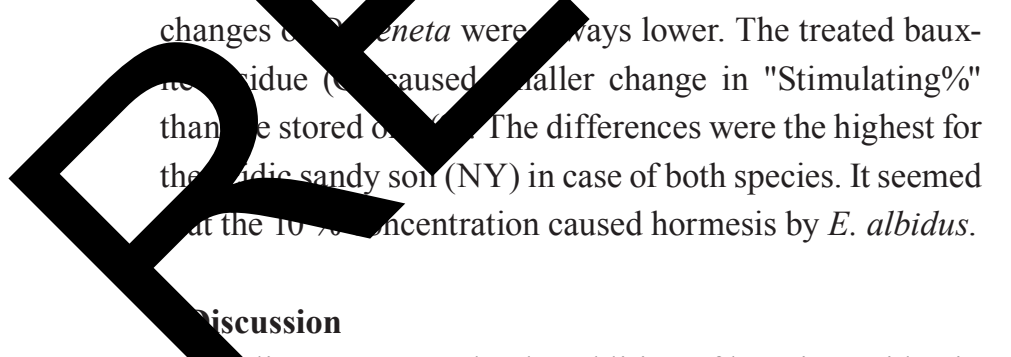

Ac ding to our results the addition of bauxite residue in a low concentration (S: $5 \%$; G: $10 \%$ ) could improve the environmental circumstances of Dendrobaena veneta and Enchytraeus albidus species in acidic soil having insufficient water holding capacity.
The improving effects of bauxite residue addition depend on the original properties of soil and bauxite residue [41-44]. The material is able to increase the $\mathrm{pH}$ level of soils $[6,7,45]$. The $\mathrm{pH}$ increasing might have been positive in case of acidic soils (NY) and it was unpleasant by other two soils (NH, OB). Related to originally neutral or slightly alkaline soil (NH, OB) the further increasing had no ecotoxicology advantages. Moreover, the bauxite residue addition can rise the water holding capacity of soils $[7,46]$. Facing these studies only the higher concentrations ( $>10 \%)$ affected in a significant way. On the other hand, the bauxite residue usually contains some potentially toxic concentrations of elements and metals [47-49].

We found that the application was safe at lower concentrations $(<10 \%)$, as it was shown by Ujaczki et al. [7, 50] and Kerekes and Feigl [29]. Due to this aspect, we should pay attention to the original metal contamination of soils before using the bauxite residue to improve different soils. 
Table 9 Average motion-frequency changing (Stimulating\%) with factorizing to gypsum treated experimental series controls (G: gypsum treated-, S: stored bauxite residue, BRX: concentration of bauxite residue, NH: Nagyhörcsök, NY: Nyírlugos, OB: Örbottyán)

\begin{tabular}{|c|c|c|c|}
\hline & $\mathrm{NH}$ & NY & OB \\
\hline \multicolumn{4}{|c|}{ Dendrobaena veneta } \\
\hline G-BR5 & $12.5 \pm 2.4$ & $19.1 \pm 2.6$ & $11.1 \pm 1.1$ \\
\hline G-BR10 & $35.4 \pm 0.9$ & $38.1 \pm 2.3$ & $40.7 \pm 1.9$ \\
\hline G-BR25 & $33.3 \pm 1.8$ & $66.7 \pm 8.7$ & $70.4 \pm 9.6$ \\
\hline G-BR50 & $45.8 \pm 2.3$ & $85.7 \pm 6.6$ & $118.5 \pm 7.0$ \\
\hline S-BR5 & $25.0 \pm 2.5$ & $171.4 \pm 34.3$ & $20.0 \pm 4.0$ \\
\hline S-BR10 & $29.2 \pm 1.6$ & $182.1 \pm 20.3$ & $16.0 \pm 2.7$ \\
\hline S-BR25 & $91.7 \pm 3.5$ & $235.7 \pm 19.6$ & $24.0 \pm 2.6$ \\
\hline S-BR50 & $95.8 \pm 7.1$ & $246.4 \pm 11.5$ & $28.0 \pm 2.5$ \\
\hline \multicolumn{4}{|c|}{ Enchytraeus albidus } \\
\hline G-BR5 & $147.4 \pm 11.1$ & $125.9 \pm 33.6$ & $149.1 \pm 22.7$ \\
\hline G-BR10 & $2.7 \pm 4.7$ & $78.9 \pm 5.6$ & $89.5 \pm 10.5$ \\
\hline G-BR25 & $12.2 \pm 2.3$ & $100.0 \pm 8.4$ & $130.7 \pm 15.4$ \\
\hline G- BR50 & $73.0 \pm 9.4$ & $128.5 \pm 5.1$ & $103.5 \pm 42.5$ \\
\hline S-BR5 & $36.3 \pm 2.1$ & $4.7 \pm 0.2$ & $8.5 \pm 0.6$ \\
\hline S-BR10 & $55.1 \pm 2.3$ & $7.6 \pm 0.3$ & $12.2 \pm 0.8$ \\
\hline S-BR25 & $69.9 \pm 2.7$ & $16.7 \pm 0.8$ & 20.5 \\
\hline S-BR50 & $83.0 \pm 4.5$ & $21.8 \pm 1.3$ & $24.1 \pm 1$ \\
\hline
\end{tabular}

Although the earthworm acute mortality test is recom mended characterizing the ecotoxicolo ferent types of waste [51], we found at the ba tite residue addition had no acute morta effect op This result fits to Maddock it confirms Courtney et a 6 results, did not find acute toxic effects in ca volobophora A. longa (especially case on untreated fres sample). The lower conce ations $(<10 \%$ both types of bauxite residue $\left(\mathrm{S}, \mathrm{G}^{\prime}\right.$ ere safe in case of bo pecies.

The $E$ Jidus was sensitive to the effect of bauxite resia dditio higher concentrations (25, 50 \%) caused sign mortality result was accordance ekes a reigl [2 esult. Although the undiluted treated auxite res a) did not have lethal effect on D. ve a hoth test species refused the higher $(25,50 \%)$ cntrations_both types of bauxite residue $(\mathrm{S}, \mathrm{G})$. bauxite residue addition influenced the behavior of bo vecies as well. The potworms were usually more resistor (except in silty soil $(\mathrm{NH}))$ related to the peristaltic motion-frequency endpoint. The originally lower motionfrequency was detected in case of $D$. veneta test species in untreated soils (C). The motion-frequency was stimulated more compared to E. albidus because of the originally lower motion- frequency of $D$. veneta. We confirmed the literature data, the motion frequency is different in case of Annelida species with different body size or mass [51-53].

As it was found earlier, the soil type influen mais behavior [54]. Taking into consideration the da we foun that the lowest concentrations $(<10 \%)$ were not only safe but could also improv acidic or sandy soils. Since the soil $\mathrm{pH}$ can $y$ limitin ctor on earthworm distribution [55], th be positive in acidic soil. Alt gh the mum range is $6.8-7.0$ with $55 \%$ so noisture, the animals can tolerate $4.8 \mathrm{pH}[50$, spite this dit, we found that the anip could survive her nel (max. $\sim 9 \mathrm{pH}$ ) in a sh te $\mathrm{tt}$ is in highe ordance with Graefe and Schmelz [57] tts, that this species tolerated slightly or acid cond ns too.

T D. veneta prefers slight, oasic $\mathrm{pH}$ level and the spe es has high meiture tolerance (67.4-84.3\%) [58]. Th is no accurate formation about $\mathrm{pH}$ tolerance or opti n of $D$. vene but generally the earthworm species tol wid a range (e.g. Eisenia fetida 5-9 soil Ulevel) [59].

$\mathrm{pH}$ and water holding capacity increasing atures or moderated bauxite residue addition, we can utilize this material to optimize the circumstances in the degradated or acidified soils. This hypothesis was conirmed by Ujaczki et al. [7, 50], Finngean et al. [28] and Kerekes and Feigl [29] results.

\section{Conclusion}

The bauxite residue addition could improve the properties of acidic or degradated soils. When the soil $\mathrm{pH}$ is neutral or higher, we should pay attention that, the bauxite residue addition is likely to cause further $\mathrm{pH}$ level increase. All the concentrations increased the $\mathrm{pH}$ level of soils. In case of acidic sandy soil (NY) $<2.5 \%$ (S) or $<5 \%$ (G) bauxite residue addition raised the $\mathrm{pH}$ level in neutral class. The addition of lower concentrations $(<10 \%)$ were safe according to XRF analysing related to all the types of soil.

The untreated bauxite residue (S) caused significant mortality on potworms in case of higher concentrations (25; $50 \%)$. The addition of gypsum was likely to reduce the potential lethal effect of material on annelids by this type of bauxite residue.

Both types of bauxite residue influenced the behavior of the animals. The increase of motion-frequency was concentration-depended. Both species refused the higher 
concentrations $(25 ; 50 \%)$. In this research, the bauxite residue was a possible soil-ameliorant material by acidic soil with inefficient water holding capacity. The treated bauxite residue had fewer toxic effects and was safe in bigger concentrations. Therefore, the treated bauxite residue seems to be a better soil ameliorant material. In the future it will be recommended investigating the ecotoxicological and environmental effects of different types of bauxite residue mixed with other acidic or/and sandy soils.

According to our and the literature information the smaller concentrations of bauxite residue is likely not to have ecotoxicological risks and the material is able to improve a few soil properties. It is necessary to examine the potential long-term effects of the utilization as soil ameliorant material, because it may be a well-appropriate reusable option. Furthermore, we should collect more information about the short- and long-term sensitivities of other taxonomic group before the field application.

\section{References}

[1] Australian Aluminium Council Ltd. "World Aluminium Residues Management: Best Practice", 2004, [online] at: http://aluminium.org.au/_literature_175772/Bauxite_ Management_-_Best_Practice_(IAI) [Accessed: 03 May 20 Power, G., Gräfe, M., Klauber, C. "Bauxite recissues: I. Cu management, disposal and storage pr 108(1-2), pp. 33-45, 2011. https://doi.org/10.1016/j.hydrom

[3] Klauber, C., Gräfe, M., options for residue pp. 11-32, 2011. https://doi.org/

[4] Liu, W., Chen, X,Li, W., Y. Yan, K. "Envirormental assessment, may nent and utilizatio red mud in China", Journal of Cleane oduction, 84, pp. 606-61 4 .

[5]

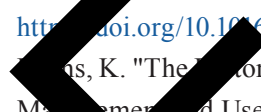

, Challenges, and New Developments in the Ma Use of Bay Residue", Journal of Sustainable Metal 2(4), pp. $316,2016$. tps://dol 0.100 831-016-0060-x ediment and soilmended with bauxite residue in the catchment of Ind Harvey Estuary, Western Australia", Agriculture, Ecosystems and Environment, 64(3), pp. 219-232, 1997. https://doi.org/10.1016/S0167-8809(97)00040-6 Ujaczki, É., Feigl, V., Farkas, É., Vaszita, E., Gruiz, K., Molnár, M. Red mud as acidic sandy soil ameliorant: a microcosm incubation study", Journal of Chemical Technology and Biotechnology, 91(6), pp. 1596-1606, 2016. https://doi.org/10.1002/jctb.4898

[8] Castaldi, P., Melis, P., Silvetti, M., Deiana, P., Garau, G. "Influence of pea wheat growth on $\mathrm{Pb}, \mathrm{Cd}$ and $\mathrm{Zn}$ mobility and soil biological status in a polluted amended soil", Geoderma, 151(3-4), pp. 241-248, 2009. https://doi.org/10.1016/j.geoderma.2009.04.009
Although we did not find significant risk in case of less concentrations $(<10 \%)$, the examiners should focus on the sublethal and chronic effects of addition (e.g. avoidance, reproduction) in the future.

\section{Acknowledgment}

We wish to thank the financial support these projects [OTKA PD 121172; H2020-EU 73010 We would like to say thanks for Vikt Feigl, Móni Molp and the members of En nmental crobiolos and Biotechnology researah g a in culty of Chemical Technology and Bi chnolog. provide us bauxite residue sample their help. thank Gábor Bakonyi for of advice. Wh thank the experts of Departmen. Biology in University of Osijek from species sp sing. We are grateful to Rita

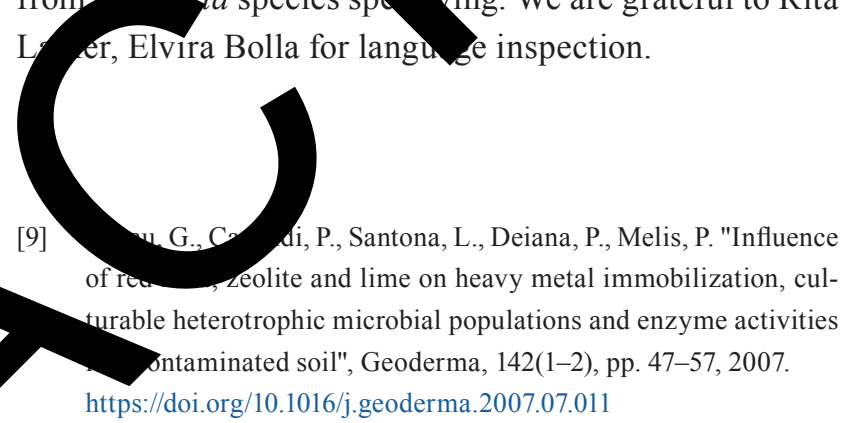

[10] Feigl, V., Anton, A., Uzinger, N., Gruiz, K. "Red Mud as a Chemical Stabilizer for Soil Contaminated with Toxic Metals", Water, Air, and Soil Pollution, 223(3), pp. 1237-1247, 2012. https://doi.org/10.1007/s11270-011-0940-4

[11] Borra, C. R., Blanpain, B., Pontikes, Y., Binnemans, K., Van Gerven, T. "Recovery of Rare Earths and Other Valuable Metals From Bauxite Residue (Red Mud): A Review", Journal of Sustainable Metallurgy, 2(4), pp. 365-386, 2016. https://doi.org/10.1007/s40831-016-0068-2

[12] Perreault, J. M., Whalen, J. K. "Earthworm burrowing in laboratory microcosms as influenced by soil temperature and moisture", Pedobiologia, 50(5), pp. 397-403, 2006. https://doi.org/10.1016/j.pedobi.2006.07.003

[13] Blouin, M., Hodson, M. E., Delgado, E. A., Baker, G., Brussaard, L., Butt, K. R., Dai, J., Dendooven, L., Peres, G., Tondoh, J. E., Cluzeau, D., Brun, J. J. "A review of earthworm impact on soil function and ecosystem services", European Journal of Soil Science, 64(2), pp. 161-182, 2013. https://doi.org/10.1111/ejss.12025

[14] van Groenigen, J. W., Lubbers, I. M., Vos, H. M. J., Brown, G. G., De Deyn, G. B., van Groenigen, K. J. "Earthworms increase plant production: a meta-analysis", Scientific Reports, 4(1), Article number: 6365, 2014. https://doi.org/10.1038/srep06365

[15] van Gestel, C. A. M., van Straalen, N. M. "Ecotoxicological Test Systems for Terrestrial Invertebrates", In: Donker, M. H., Eijsackers, H., Heimbach, F. (eds.) Ecotoxicology of Soil Organism, Lewis Publishers, Boca Raton, FL, USA, 1994, pp. 205-225. 
[16] Chapman, E. E. V., Dave, G., Murimboh, J. D. "A review of metal $(\mathrm{Pb}$ and $\mathrm{Zn})$ sensitive and $\mathrm{pH}$ tolerant bioassay organisms for risk screening of metal-contaminated acidic soils", Environmental. Pollution, 179, pp. 326-342, 2013.

https://doi.org/10.1016/j.envpol.2013.04.027

[17] International Organization for Standardization "ISO 112681:2012 Soil quality — Effects of pollutants on earthworms Part 1: Determination of acute toxicity to Eisenia fetida/Eisenia andrei", International Organization for Standardization, Geneva, Switzerland, 2014. [online] Available at: https://www.iso.org/ standard/53527.html [Accessed: 02 April 2020]

[18] International Organization for Standardization "ISO 11268-2:2012 Soil quality - Effects of pollutants on earthworms - Part 2: Determination of effects on reproduction of Eisenia fetida/Eisenia andrei", International Organization for Standardization, Geneva, Switzerland, 2014. [online] Available at: https://www.iso.org/ standard/53528.html [Accessed: 02 April 2020]

[19] International Organization for Standardization "ISO 11268-3:2014 Soil quality - Effects of pollutants on earthworms - Part 3: Guidance on the determination of effects in field situations", International Organization for Standardization, Geneva, Switzerland, 2014. [online] Available at: https://www.iso.org/ standard/57583.html [Accessed: 02 April 2020]

[20] International Organization for Standardization "ISO 16387:2004Soil quality - Effects of pollutants on Enchytraeidae (Enchytraeu Determination of effects on reproduction and survival", Internat Organization for Standardization, Geneva, Switzerland, 20 [online] Available at: https://www.iso.org/standard/30946.htn [Accessed: 02 April 2020]

[21] International Organization for Standardy Soil quality - Avoidance test for and effects of chemicals on behayi (Eisenia fetida and Eisenia ay Standardization, Geneva

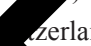
Intern Organization for zerland, 2008. Available at https://www.iso.org/st 02.html [Accesse April 2020]

[22] Organisation for onomic operation and Nelopment "Test No. 207: F thworm, Acute To vests", OECD Guidelines for the Test of Chemicals, Section ECD Publishing, Paris,

hiltorg/10.17 89264070042-en

23] Orgat ion f conomic Co-operation and Development "Test No. chytraeid $\mathrm{B}$ duction Test", OECD Guidelines

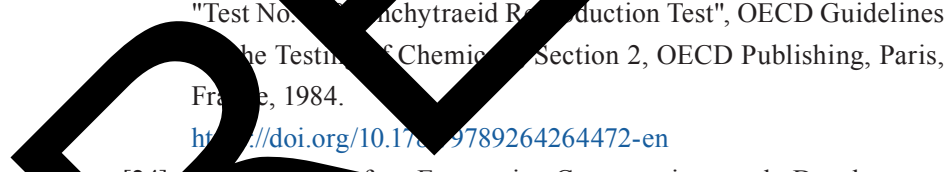

247 Economic Co-operation and Development "Test No. 222: Earthworm Reproduction Test (Eisenia fetidal Eisenia andrei)", OECD Guidelines for the Testing of Chemicals, ction 2, OECD Publishing, Paris, France, 1984. //doi.org/10.1787/9789264264496-en

[25] Maddock, G., Reichelt-Brushett, A., McConchie, D., Vangronsveld, J. "Bioaccumulation of metals in Eisenia fetida after exposure to metal-loaded Bauxol ${ }^{\mathrm{TM}}$ reagent", Environmental Toxicology and Chemistry, 24(3), pp. 554-563, 2005. https://doi.org/10.1897/04-087R.1
[26] Courtney, R., Di Carlo, E., Schmidt, O. "Soil properties and earthworm populations associated with bauxite residue rehabilitation strategies", Environmental Science and Pollution Research, 27(27), pp. 33401-33409, 2020. https://doi.org/10.1007/s11356-018-3973-z

[27] Di Carlo, E., Boullemant, A., Poynton, H., Cou of earthworm (Eisenia fetida) to bauxite for future rehabilitation programmes", S Environment, 716, Article number: 137 https://oi.org/10.1016/j.scitotenv.2

[28] Finngean, G., O’Grady, A., ance tests with collembola itation success in baux Pollution Research https://doi.org/1

[29] Kerekes, I.K. Behavior
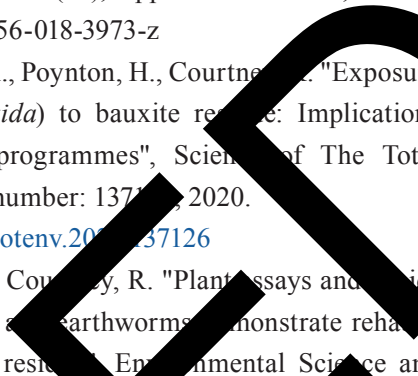
Polytechnica Chemical Engh g, 62(4), pp. 415-425, 2018.

[30] oHack.org "GeoHack - Ajkà Timföldgyár" (GeoHack Alumina factory ip jka), [online] Available at: https://geohack. polforge.org/geoh php?language $=$ hu \&pagename $=$ Ajkai nf $\%$ C3\%B6ldgy $3 \% A 1$ r\&params $=47.088461 ; 17.547803$ t) ndmark [A 16 October 2020] (in Hungarian)

31] Spark mnia: Filtration in the alumnia production rocess", [online] Available at: https://www.filtsep.com/oilSeatures/alumina-filtration-in-the-alumina-production/ [Accessed: 16 October 2020]

[32] Hungarian Standards Institution "MSZ-08-0206-2:1978 A talaj egyes kémiai tulajdonságainak vizsgálata. Laboratóriumi vizsgálatok. (pH-érték, szódában kifejezett fenolftalein lúgosság, vízben oldható összes só, hidrolitos ( $\mathrm{y}^{`} 1^{\wedge}$-érték) és kicserélődési aciditás (y`2^-érték))" (Evaluation of some chemical properties of the soil. Laboratory tests. ( $\mathrm{pH}$ value, phenolphthalein alkalinity expressed in soda, all water-soluble salts, hydrolyte $\left(\mathrm{y}^{`} 1^{\wedge} \_\right.$-value and exchanging acidity ( $\mathrm{y}^{`} 2^{\wedge}$ - value) $)$, MSZT, Budapest, Hungary, 1978. (in Hungarian)

[33] Öhlinger, R. "Maximum water-holding capacity", In: Schinner, F., Öhlinger, R., Kandeler, E., Margesin, R. (eds.) Methods in soil biology, Springer-Verlag, Berlin, Germany, 1996, pp. 385-386.

[34] Hungarian Standards Institution "MSZ 21470-2:1981 Környezetvédelmi talajvizsgálatok. talajminta előkészítése, nedvességtartalom, elektromos vezetés és pH meghatározása" (Environmental protection. Preparation of soil sample. Determination of electrical conduction, humidity and $\mathrm{pH}$ ), MSZT, Budapest, Hungary, 1981. (in Hungarian)

[35] United States Department of Agriculture "SSM - Ch. 3. Examination and Description of Soil Profiles", [online] Available at: https://www.nrcs.usda.gov/wps/portal/nrcs/detail/soils/ ref/?cid=nrcs142p2_054253 [Accessed: 03 April 2020]

[36] Loureiro, S., Soares, A. M. V. M., Nogueira, A. J. A. "Terrestrial avoidance behaviour tests as screening tool to assess soil contamination", Environmental Pollution, 138(1), pp. 121-131, 2005. https://doi.org/10.1016/j.envpol.2005.02.013 
[37] Allison, P. D. "Convergence Failures in Logistic Regression", In: SAS Global Forum 2008, San Antonio, TX, USA, 2008, Paper number: 360-2008. [online] Available at: https://www. semanticscholar.org/paper/Convergence-Failures-in-LogisticRegression-Allison/4f171322108dff719da6aa0d354d5f73c9c47 4de [Accessed: 16 October 2020]

[38] Myers, R. H., Montgomery, D. C., Vining, G. G., Robinson, T. J. "Generalized Linear Models: with Applications in Engineering and the Sciences", Wiley, Hoboken, NJ, USA, 2010.

[39] Wolters Kluwer Net Jogtár "6/2009. (IV. 14.) KvVM-EüM-FVM együttes rendelet a földtani közeg és a felszín alatti víz szennyezéssel szembeni védelméhez szükséges határértékekről és a szennyezések méréséről" (6/2009 (IV. 14.) KvVM-EuM-FVM decree laying down limits necessary for the protection of geological medium and groundwater against pollution and on measurements of pollutants), KvVM-EüM-FVM, Budapest, Hungary, 2009. [online] Available at: https://net.jogtar.hu/jogszabaly?docid=a0900006.kvv [Accessed: 16 October 2020] (in Hungarian)

[40] Swartjes, F. A. "Risk-Based Assessment of Soil and Groundwater Quality in the Netherlands: Standards and Remediation Urgency", Risk Analysis, 19(6), pp. 1235-1249, 1999. https://doi.org/10.1111/j.1539-6924.1999.tb01142.x

[41] Carter, C. M., van der Sloot, H. A., Cooling, D., van Zomeren, A., Matheson, T. "Characterization of Untreated and Neutralized Bauxite Residue for Improved Waste Management", Envi Engineering Science, 25(4), pp. 475-488, 2008. https://doi.org/10.1089/ees.2006.0234

[42] Liu, W., Yang, J., Xiao, B. "Review on treatment and of bauxite residues in China", Intern Processing, 93(3-4), pp. 220-231, https://doi.org/10.1016/j.minpro.2

[43] Gräfe, M., Power, G., III. Alkalinity and 108(1-2), pp. 60-79, https://doi.org/10.

[44] Xue, S., Kong, Zhu, P., tley, W., Li, X., , Y. "Proposal for manage nnt and alkalinity sormation of bauxite residue in Chin Avironmental Science Pollution Research, 23(13),

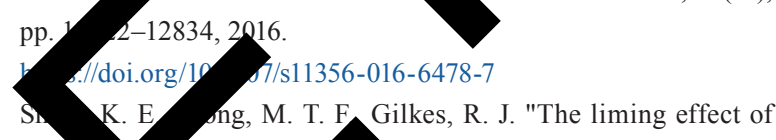
baux dssing residy mud) on sandy soils", Australian purnal o (3), pp. 321-328, 2004. ps://doi.or SR03021 uchanan, S. J. so, H. B., Kopittke, P. M., Menzies, N. W. xture in bauxite residues on void ratio, water holding characteristics, and penetration resistance", Geoderma, 158(3-4), pp. 421-426, 2010.

https://doi.org/10.1016/j.geoderma.2010.06.016

[47 Surke, I. T., Peacock, C. L., Lockwood, C. L., Stewart, D. I., Mortimer, R. J. G., Ward, M. B., Renforth, P., Gruiz, K., Mayes, W. M. "Behavior of Aluminum, Arsenic and Vanadium during the Neutralization of Red Mud Leachate by HCl, Gypsum, or Seawater", Environmental Science and Technology, 47(12), pp. 6527-6535, 2013.

https://doi.org/10.1021/es4010834
[48] Rubinos, D., Spagnoli, G., Barral, M. T. "Assessment of bauxite refining residue (red mud) as a liner for waste disposal facilities", International Journal of Mining, Reclamation and Environment, 29(6), pp. 433-452, 2013. https://doi.org/10.1080/17480930.2013.830906

[49] Mayes, W. M., Burke, I. T., Gomes, H. I., Anto Feigl, V., Ujaczki, É. "Advances in Unders Risks of Red Mud After the Ajka Spill, Sustainable Metallurgy, 2(4), p https://doi.org/10.1007/s40831

[50] Ujaczki, É., Klebercz, Uzinger, N., Gruiz, K. the Spilled Ajka Re Mud ocosms for Potential Utilisation as Soi Meliorant', dica Polyted a Chemical
Engineering, pp. 253-261, 20 https:/doj MPch.7839

[51] Pandard, A., Devi J., Charissou, A.-M., Poulsen, V., Jourdain, M.-J., Férard, - Grand, C., Bispo, A. "Selecting a batoussays for ecotox gical characterization of wastes", Science of The Total Environmunt, 363(1-3), pp. 114-125, 2006. https://doi.org/10 16/j.scitotenv.2005.12.016

Keudel, M., Sch er, S. "Axial and radial pressure exerted by earthworms of o rent ecological groups", Biology and Fertility Soils, 29(3) 262-269, 1999.

hty 10.1007/s003740050551

Quillin, K. J. "Kinematic scaling of locomotion by hydrostatic ls: ontogeny of peristaltic crawling by the earthworm Lumbricus terrestris", Journal of Experimental Biology, 202(6), pp. 661-674, 1999.

https://doi.org/10.1242/jeb.202.6.661

[54] Ruiz, S. A., Or, D. "Biomechanical limits to soil penetration by earthworms: direct measurement of hydroskeletal pressures and peristaltic motions", Journal of the Royal Society Interface, 15(144), Article number: 20180127, 2018. https://doi.org/10.1098/rsif.2018.0127

[55] Peijnenburg, W., Capri, E., Kula, C., Liess, M., Luttik, R., Montforts, M., Nienstedt, K., Römbke, J., Sousa, J. P., Jensen, J. "Evaluation of Exposure Metrics for Effect Assessment of Soil Invertebrates", Critical Reviews in Environmental Science and Technology, 42(17), pp. 1862-1893, 2012. https://doi.org/10.1080/10643389.2011.574100

[56] Jänsch, S., Amorim, M. J., Römbke, J. "Identification of the ecological requirements of important terrestrial ecotoxicological test species", Environmental Reviews, 13(2), pp. 51-83, 2005. https://doi.org/10.1139/a05-007

[57] Graefe, U., Schmelz, R. M. "Indicator values, strategy types and life forms of terrestrial Enchytraeidae and other microannaelids", Newsletter on Enchytraeidae, 6, pp. 59-67, 1999.

[58] Smith, T. J., Stringfellow, W. T. "Identification of Factors from Agricultural Runoff Water on the Viability of Embryos of the Earthworm Dendrobaena veneta", Dynamic soil, Dinamic Plant, 4(1), pp. 159-161, 2010. [online] Available at: http://www.globalsciencebooks.info/Online/GSBOnline/ images/2010/DSDP_4(SI1)/DSDP_4(SI1)159-161o.pdf [Accessed: 10 February 2020] 
[59] Edwards, C. A., Arancon, N. Q. "The Science of Vermiculture: The Use of Earthworms in Organic Waste Management", In: Guerrero III, R. D., Guerrero-del Castillo, M. R. A. (eds.) Vermi Technologies for Developing Countries. Proceedings of the International Symposium-Workshop on Vermi Technologies for Developing Countries, Philippine Fisheries Association Inc., Los Baños, CA, USA, 2005, pp. 1-25.

\section{Appendix A}

Table 10 As, Cr and V content of BR treated soils. Bold: amount >threshold value (As, Cr: Hung. 6/2009 [39]; V: Detection Limit, T. H.: Threshold value, S: stored-, G: gypsum treated bauxite residue, NH: Nagyhörcsök,

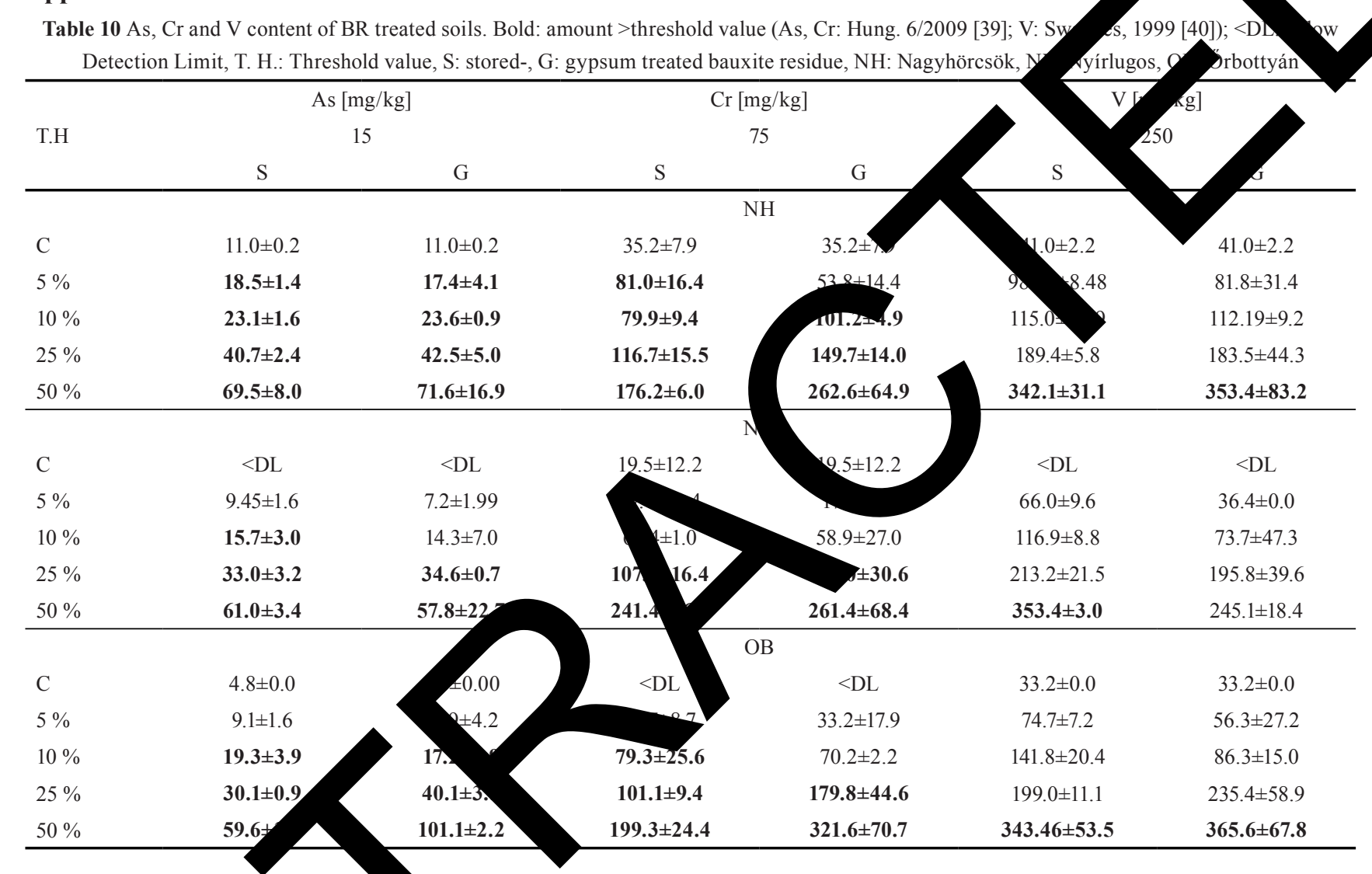

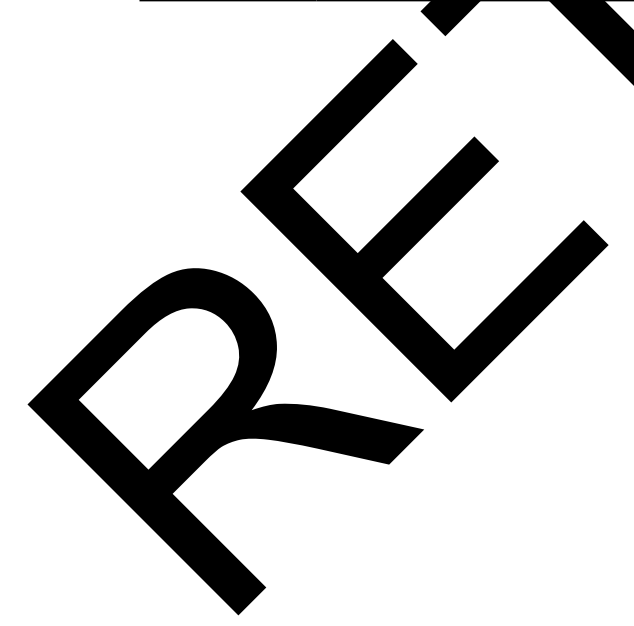


Appendix B
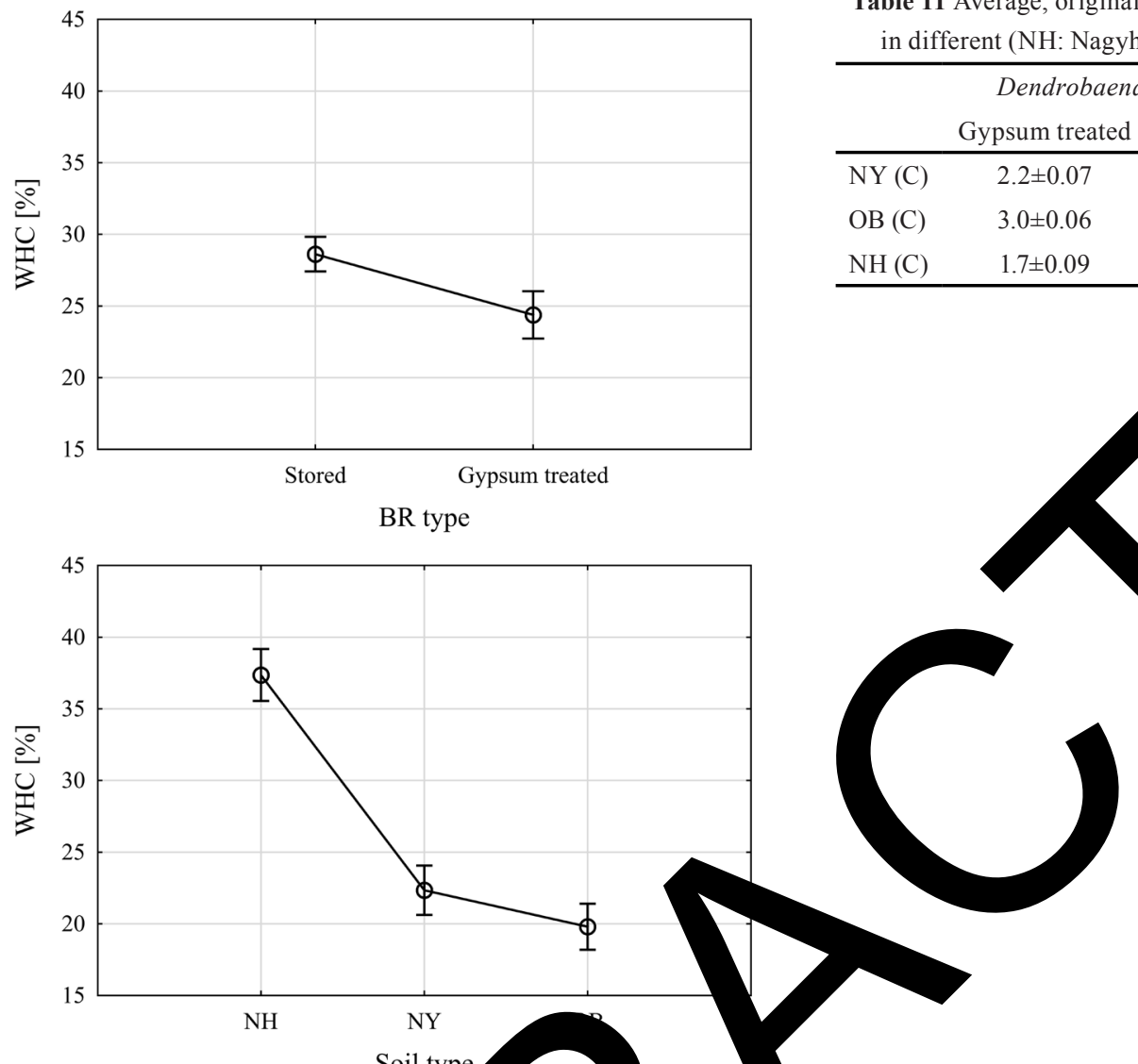

\section{Appendix C}

Table 11 Average, original motion-frequency of different test species in different (NH: Nagyhörcsök, NY: Nyírlugos, OB: Örbottyán)

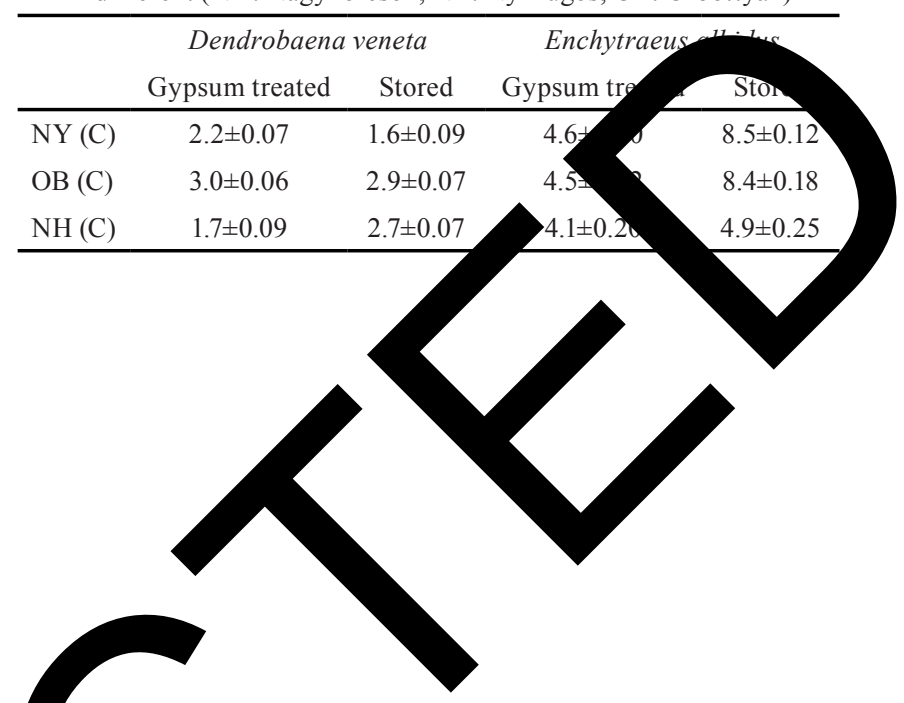

